\title{
Characterizing Rice Lesion Mimic Mutants and Identifying a Mutant with Broad-Spectrum Resistance to Rice Blast and Bacterial Blight
}

\author{
Zhongchao Yin, ${ }^{1}$ Jun Chen, ${ }^{1}$ Lirong Zeng, ${ }^{1}$ Meiling Goh, ${ }^{2}$ Hei Leung ${ }^{3}$ Gurdev S. Khush, ${ }^{3}$ \\ and Guo-Liang Wang ${ }^{1,4}$ \\ ${ }^{1}$ Institute of Molecular Agrobiology, The National University of Singapore, 1 Research Link, Singapore \\ 117604, Republic of Singapore; ' ${ }^{2}$ Singapore Polytechnic, 500 Dover Road, Singapore 139651, Republic \\ of Singapore; ${ }^{3}$ International Rice Research Institute, PO Box 3127, 12171 Makati City, Philippines; \\ ${ }^{4}$ Department of Plant Pathology, The Ohio State University, Kottman Hall, 2021 Coffey Road, Columbus \\ 43210-1087, U.S.A. \\ Accepted 27 April 2000.
}

\begin{abstract}
Many plant mutants develop spontaneous lesions that resemble disease symptoms in the absence of pathogen attack. In several pathosystems, lesion mimic mutations have been shown to be involved in programmed cell death, which in some instances leads to enhanced disease resistance to multiple pathogens. We investigated the relationship between spontaneous cell death and disease resistance in rice with nine mutants with a range of lesion mimic phenotypes. All nine mutations are controlled by recessive genes and some of these mutants have stunted growth and other abnormal characteristics. The lesion mimics that appeared on the leaves of these mutants were caused by cell death as measured by trypan blue staining. Activation of six defense-related genes was observed in most of the mutants when the mimic lesions developed. Four mutants exhibited significant enhanced resistance to rice blast. One of the mutants, spl11, confers non-race-specific resistance not only to blast but also to bacterial blight. The level of resistance in the spl11 mutant to the two pathogens correlates with the defense-related gene expression and lesion development on the leaves. The results suggest that some lesion mimic mutations in rice may be involved in disease resistance, and cloning of these genes may provide a clue to developing broad-spectrum resistance to diverse pathogens.
\end{abstract}

Additional keywords: hypersensitive response, Magnaporthe grisea, Xanthomonas oryzae pv. oryzae.

The interaction between a plant resistance gene and the corresponding avirulence gene of the pathogen triggers a series of defense responses (Bent 1996; Hammond-Kosack

Corresponding author: Guo-Liang Wang, Department of Plant Pathology, The Ohio State University, Kottman Hall, 2021 Coffey Road, Columbus 43210-1087, U.S.A.: Telephone: 1-(614) 292 9280; Fax: 1-(614) 292 4455; E-mail: wang.620@osu.edu

* The $e$-Xtra logo stands for "electronic extra" and indicates the HTML abstract available on-line contains supplemental material not included in the print edition. and Jones 1996). One of the most common features is localized cell death at the infection site, known as hypersensitive response (HR). The HR is correlated with a transient burst of active oxygen species, activation of specific defense-related genes, accumulation of antimicrobial compounds, and alterations of the plant cell wall (HammondKosack and Jones 1996; Dangl et al. 1996). It has been documented in many plant species that HR is associated with increased resistance throughout the plant to subsequent infection by different pathogens (reviewed by Ryals et al. 1996). This latter phenomenon is termed systemic acquired resistance (SAR). Expression of pathogenesis-related $(P R)$ genes and elevated levels of salicylic acid (SA) were observed in the establishment of SAR (Ward et al. 1991; Gaffney et al. 1993).

Considerable efforts have been made to identify the events that trigger HR, and to define the steps that culminate in cell death. One way to find the basis of HR is to use mutants with a visible phenotype that resembles the disease lesions caused by pathogen attack. Such lesion mimic mutants have been identified in Arabidopsis (Greenberg and Ausubel 1993; Dietrich et al. 1994), maize (Walbot et al. 1983; Johal et al. 1995; Morris et al. 1998), barley (Wolter et al. 1993), and rice (Kiyosawa 1970; Marchetti et al. 1983; Takahashi et al. 1999). The disease or HR-like lesions also appear in the absence of pathogens at certain developmental stages (Dietrich et al. 1994; Greenberg et al. 1994; Johal et al. 1995; Wolter et al. 1993; Takahashi et al. 1999). The lesion mimic phenotypes associated with these mutants imply that they may represent steps involved in normal response pathways triggered by pathogen infection. Further studies showed that these mutants express histochemical and molecular markers associated with disease resistance response, have elevated levels of SA, and show enhanced resistance to bacterial and oomycete pathogens when lesions are present (Dietrich et al. 1994; Morris et al. 1998; Takahashi et al. 1999) or before lesions occur (Dietrich et al. 1994; Buschges et al. 1997). In addition, derivative alleles at the resistance gene Rpl locus in maize show lesion mimic phenotypes, suggesting that misregulation of resistance gene function may also lead to cell death (Hu et al. 1996). 
To date, four genes responsible for the lesion mimic mutations in Arabidopsis, maize, and barley have been cloned. The Arabidopsis $l s d l$ mutant was hyper-responsive to challenge by a variety of stimuli and resistant to virulent pathogens at a state when no lesions were observed on the leaves (Dietrich et al. 1994). The predicted LSD1 protein contains three zinc finger domains, suggesting that LSD1 may regulate transcription via either repression of a pro-death pathway or activation of an "anti-death" pathway, in response to signals from cells undergoing pathogen-induced, hypersensitive cell death (Dietrich et al. 1997). Recently, Kliebenstein et al. (1999) found that $L S D 1$ is a part of a signaling pathway for the induction of the CuZnSOD proteins responsible to SA but not in $l s d l$-mediated cell death. Therefore, it was speculated that the spreading of lesion phenotype of $l s d l$ is due to lack of a upregulated $\mathrm{CuZnSOD}$ protein that can cause detoxification of accumulating superoxide. The barley lesion mimic gene mlo confers broad-spectrum resistance to almost all known isolates of Erysiphe graminis f. sp. hordei and exhibits a spontaneous cell death phenotype under pathogen-free conditions (Jorgensen 1992; Buschges et al. 1997). The gene encodes a $60-\mathrm{kDa}$ protein that is predicted to be membrane anchored by at least six membrane-spanning helices. It is possible that Mlo has a dual negative control function in cell death and in the initiation of disease resistance to powdery mildew (Buschges et al. 1997). Interestingly, the mlo mutations in barley appeared to result in enhanced susceptibility to the rice blast fungus (Jarosch et al. 1999). The third cloned lesion mimic gene is maize Llsl, which was found to have elevated resistance to two fungal pathogens (Simmons et al. 1998) and was cloned by transposon tagging (Gray et al. 1997). Two conserved motifs resembling those found in aromatic ringhydroxylating dioxygenases are present in the predicted LLS1 protein, suggesting that it may limit cell death by degrading a phenolic mediator of cell death (Gray et al. 1997). Not all lesion mimic genes are necessarily involved in pathogen recognition and resistance response pathways. For example, the maize lesion mimic gene Les 22 encodes uroporphyrinogen decarboxylase (UROD), a key enzyme in the biosynthetic pathway of chlorophyll and heme in plants (Hu et al. 1998).

The first rice lesion mimic mutant, called Sekiguchi lesion (sl) mutant, was identified in the early 1970s. A tight linkage between the lesion mimic gene and blast resistance gene Pita was observed (Kiyosawa 1970). Marchetti et al. (1983) identified a recessive lesion mimic mutant in which lesion formation was induced by pathogens (Bipolaris oryzae and Magnaporthe grisea) and certain chemical agents. Recently, Takahashi et al. (1999) found three lesion mimic mutants that showed high expression of two defense-related genes, $P R I$ and $P B Z 1$, and elevated resistance to a single blast isolate in Japan. They also provided evidence that the two lesion mimic genes reside in the early signaling steps that lead to the activation of NADPH oxidase. To further investigate the role of cell death in disease resistance to rice pathogens, we characterized nine rice lesion mimic mutants previously identified by various researchers and mapped to different chromosomal locations (Kinoshita 1995). These mutants express cytological characteristics of cell death, and some show unique expression patterns of biochemical markers with potential roles in SAR and oxidative burst. Interestingly, one of the mutants, spll1, confers high levels of resistance to multiple blast and bacterial blight isolates.

\section{RESULTS}

\section{Mutant phenotypes.}

G. S. Khush and A. C. Sanchez (unpublished data) produced a set of lesion mimic near-isogenic lines by crossing IR36 with eight spontaneous lesion mimic mutants or spotted leaf $(s p l)$ mutants ( $s p l 1,2,3,4,5,6,7$, and 9) that were identified by researchers from different rice cultivars (Kinoshita 1995). All these lesion mimic mutations are recessive and were mapped onto different chromosomal locations (Kinoshita 1995). The progeny were backcrossed three times with IR36 as the recurrent parent and self-fertilized three times to produce $\mathrm{BC}_{3} \mathrm{~F}_{3}$ homozygous lines for use in this study. The eight mutants used exhibited different lesion mimic phenotypes varying in the time of initiation and size and color of lesions. spll (considered the same as Sekiguchi lesion gene sl; Kiyosawa 1970) showed large (>10 mm long), yellow, necrotic lesions, whereas spl2 displayed large and chlorotic lesions. Mutant spl3 showed small, chlorotic, yellow lesions. The other mutants displayed small $(<3 \mathrm{~mm})$ to medium-sized ( 5 to $10 \mathrm{~mm}$ ), discrete, brown, necrotic lesions. Visible lesions appeared at the early developmental stage (2 to 3 weeks after sowing) in spll, spl2, spl3, spl4, spl5, and spl9, whereas lesions were seen about 2 months after sowing in spl6 and spl7. Some lesion mimic mutants showed abnormal developmental phenotypes. For instance, spll, spl2, and spl5 were stunted, and spl3 and spl4 were partially sterile, with spl4 bearing abnormal spikelets. spll1 was identified in an ethyl methanesulfonate (EMS)-mutagenized population of IR68 (Singh et al. 1995) and was mapped onto chromosomal 12 (Z. Yin, L. Zeng, and G.-L. Wang, unpublished). The lesions on spll1 leaves were randomly distributed on fully expanded leaves, and discrete, small, brown lesions coalesced and gradually occupied the entire leaf at the mature stage. The lesion mimic phenotypes on the mature leaves of spll, spl5, and spll1 are shown in Figure 1A.

To determine whether lesion formation in these mutants required an exogenous biotic trigger, we grew all $s p l$ mutants under sterile conditions (see Materials and Methods). The timing of lesion initiation in these mutants was the same as in plants grown in greenhouse conditions (data not shown). The result demonstrates that lesion formation in the mutants is not caused by other biotic agents.

\section{Histochemical detection of cell death and expression of defense-related genes in $s p l$ mutants.}

Three to four leaves from 6-week old plants with apparent lesions of $s p l$ mutants were stained with trypan blue, a histochemical indicator of irreversible membrane damage or cell death (Dietrich et al. 1994). Figure 1B shows deep blue staining in cells at the site of necrosis in spll, spl5, and spll1 mutants. Blue staining was not observed in the young leaves (less than 2 weeks old) of spll1 mutants in which lesion mimic could not be seen. Trypan blue staining of other $s p l$ mutants showed results similar to those of the above three mutants (data not shown). In the leaves of spll (Fig. 1B) and spl2 (data not shown), where large lesions were formed, blue staining was localized on those newly senescent and dying cells within the edge of the necrotic lesions.

mRNA accumulation of $P R$ genes was strongly correlated with the onset of SAR in dicots (Ryals et al. 1996; Yang et al. 
1997) as well as in lesion mimic mutants in both dicots and monocots (Dietrich et al. 1994; Morris et al. 1998; Takahashi et al. 1999). To test whether spontaneous lesion formation correlates with the expression of genes strongly correlated with the onset of defense response, total RNA was isolated from leaves with lesions of all the $s p l$ mutants and from leaves of the wild-type plants (IR36 and IR68). RNA blots were probed with the three types of marker genes associated with disease resistance responses: two rice $P R$ protein genes, two rice peroxidase genes, and two barley genes associated with the production of hydrogen peroxide (see Materials and Methods).

The $P R 1$ gene was reported to be induced in the resistance reaction to rice blast (Schweizer et al. 1998), whereas PBZ1, an intracellular protein, was induced by probenazole (3allyloxy-1, 2-benzisothiazole-1,1-dioxide), an effective chemical inducer of host resistance against rice blast infection (Midoh and Iwata 1996). As shown in Figure 2A, these two $P R$ protein genes were activated in all the $s p l$ mutants at different levels during lesion development. For the $P R 1$ gene, spll and spl5 showed the highest expression, whereas $s p l 7$ showed very low expression. Little or no $P R 1$ expression was detected in the wild-type plants of IR36 and IR68. The PBZ1 gene showed a relatively high expression in spll, spl4, and spll1, compared with a lower expression in other spl mutants. Interestingly, IR68 displayed a higher level of expression of the $P B Z 1$ gene than IR36.

The generation of active oxygen species has been considered a significant step during pathogen-plant interactions (Baker and Orlandi 1995; Low and Merida 1995). The $\mathrm{HvOxOa}$ gene, a major oxalate oxidase gene in barley (Hordeum vulgare), was found to be induced in response to infection by the powdery mildew fungus, Blumeria (syn. Erysiphe) graminis f. sp. hordei (Zhou et al. 1998). The barley HvOxOLP gene, which encodes an oxalate oxidase-like protein with no apparent oxalate oxidase activity, was inducible and associated with papilla resistance toward the powdery mildew fungus (Wei et al. 1998). These two genes from barley were used to detect homologous gene expression in $s p l$ mutants during lesion development. For the $\mathrm{HvOxOa}$ gene, spll and $s p l 11$ showed high expression whereas spl3, spl6, spl7, spl9, and IR68 showed detectable expression. No expression was observed in spl2, spl4, spl5, and IR36 (Fig. 2A). In contrast, the HvOxOLP gene was activated in all spl mutants, with $s p l 3$, spl5, and $s p l 9$ showing the highest expression. No expression was observed in the wild-type plants (Fig. 2A).

Peroxidases (EC1.11.1.7, $\mathrm{H}_{2} \mathrm{O}_{2}$ oxidoreductase) are extracellular enzymes that catalyze the oxidation of a variety of organic and inorganic substrates at the expense of $\mathrm{H}_{2} \mathrm{O}_{2}$ involved in many plant developmental and environmental responses (Gaspar et al. 1982). The induction of rice peroxidases POX22.3 and POX8.1 correlated with resistant interactions between rice and bacterial blight strain Xanthomonas oryzae pv. oryzae (Chittoor et al. 1997). In our study, the POX22.3 gene was highly activated in $s p l 3$, but not in other $s p l$ mutants and the wild-type plants (Fig. 2A). The expression of the POX8.1 gene could be detected only in $s p l 3$ and spll1 a week after exposure of X-ray film for autoradiography, compared with the overnight to 24-h exposure time for other probes (Fig. 2A).

As in the case of other lesion mimic mutants, lesion formation in $s p l$ mutants is developmentally regulated, with more lesions appearing in older leaves (4 weeks). To determine whether the expression of these defense-related genes correlates with lesion development, total RNA of spll1 was isolated from newly developed, young leaves without visible lesions (less than 1 week), fully expanded leaves with few lesions ( 2 weeks), and leaves with many lesions (4 weeks). The results in Figure $2 \mathrm{~B}$ show that except for the POX22.3 gene the expression of all defense-related genes showed a good correlation with the development of lesions. In contrast,
A
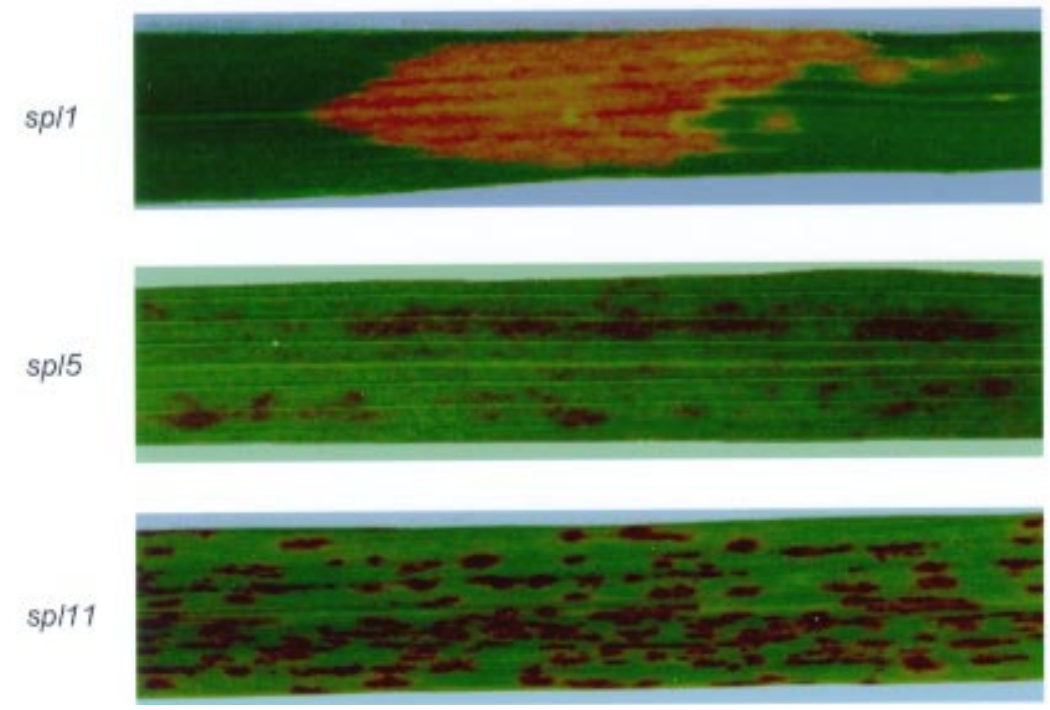

B
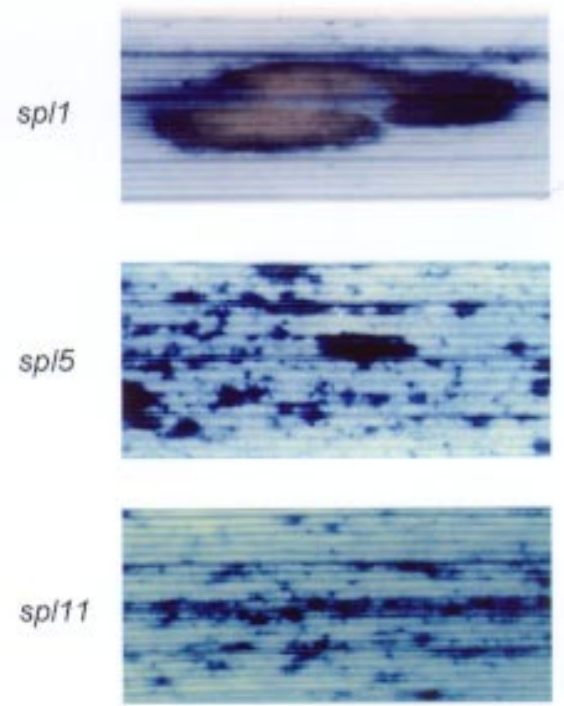

Fig. 1. Expression of histochemical markers in the $s p l$ mutants. A, Lesion mimic phenotypes of $s p l 1$, $s p l 5$, and $s p l 11$. Leaves with apparent lesion mimics were taken from 6-week-old plants. B, Trypan blue staining at and around the sites of necrosis of $s p l 1$, spl5, and $s p l 11$. Leaves similar to those in A were used. 
the POX22.3 gene showed high expression only in fully expanded leaves with few lesions, but not in leaves with many lesions. It is possible that the expression of POX22.3 was activated during the initiation of lesion formation but suppressed by the accumulation of cell death at the late growth stage. Although the expression of $P B Z 1$ increased with leaf development in IR68, it was still lower than that in spll1 (Fig. 2B).

\section{Disease reaction of $s p l$ mutants}

\section{in the IR36 genetic background to rice blast.}

Expression of the six defense-related genes suggests that some of the spl mutants may have enhanced resistance to pathogen infection, as observed in other plant species (Dietrich et al. 1994; Morris et al. 1998; Takahashi et al. 1999). To confirm this hypothesis, four rice blast isolates compatible to the recurrent parent IR36 were used to inoculate the eight lesion mimic mutants in the IR36 background. As Table 1 shows, spll, spl5, and spl9 showed lesion mimic induction but no or fewer blast disease lesions upon inoculation with four blast isolates. In spll plants, a large number of mimic lesions were formed after blast inoculation and the inoculated plants often died 1 week after inoculation. The spl5 plants were able to survive after blast infection, as the lesions were smaller than those of spll. Although spl9 showed enhanced resistance to blast isolates 9232-5 and C9214-29, more typical susceptible lesions (type 4 or 5 lesions) were produced in the plants inoculated with two relatively more virulent isolates (PO6-6 and CBN9219-25), indicating that the enhanced resistance in $s p l 9$ may not be sufficient for the plant to defend itself against more virulent isolates.

Evaluation of $\mathrm{spll}$ resistance to blast was also carried out with $40 \mathrm{~F}_{2}$ plants of a cross between spll and $\mathrm{CO} 39$, an indica cultivar highly susceptible to both blast and bacterial blight. $\mathrm{F}_{4}$ homozygous plants with lesion mimic phenotype did not produce blast disease lesions upon inoculation with those four blast isolates, whereas plants without lesion mimic were highly susceptible to the same isolates. However, the evaluation for resistance of $s p l 5$ to blast in a segregating population could not be done because it was difficult to separate lesion mimic plants from normal plants in the progeny of the cross between $s p l 5$ and CO39. As reported in other plants, spl5 lesion mimic formation may be affected by the genetic background of the plant (Johal et al. 1995).

\section{Broad-spectrum resistance to blast and bacterial blight conferred by spl11.}

Since no blast and bacterial blight isolates compatible to IR68 (wild type of spl11) were identified in our screening ex-

Table 1. Lesion mimic formation and disease reaction after inoculation with different blast isolates ${ }^{\mathrm{a}}$

\begin{tabular}{|c|c|c|c|c|c|c|c|c|c|c|}
\hline \multirow[b]{3}{*}{ Mutants } & & & \multicolumn{8}{|c|}{ Blast isolate } \\
\hline & \multicolumn{2}{|c|}{ Water } & \multicolumn{2}{|c|}{ PO6-6 } & \multicolumn{2}{|c|}{$9232-5$} & \multicolumn{2}{|c|}{ C9214-29 } & \multicolumn{2}{|c|}{$\begin{array}{c}\text { CBN9219- } \\
25\end{array}$} \\
\hline & LM & DL & $\mathbf{L M}$ & DL & LM & DL & LM & DL & LM & DL \\
\hline IR36 & 0 & 0 & 0 & + & 0 & + & 0 & + & 0 & ++ \\
\hline spll & + & 0 & ++++ & 0 & +++ & 0 & +++ & 0 & ++++ & 0 \\
\hline spl2 & + & 0 & + & $0 /+$ & + & $0 /+$ & + & 0 & + & ++ \\
\hline spl3 & + & 0 & + & + & + & + & + & 0 & +++ & ++++ \\
\hline spl4 & + & 0 & + & ++ & + & 0 & + & 0 & ++ & ++ \\
\hline spl5 & + & 0 & ++++ & 0 & +++ & 0 & +++ & 0 & +++ & 0 \\
\hline spl6 & 0 & 0 & + & ++ & + & $0 /+$ & + & + & + & ++++ \\
\hline spl7 & 0 & 0 & 0 & + & 0 & $0 /+$ & 0 & 0 & + & ++++ \\
\hline spl9 & ++ & 0 & +++ & ++ & +++ & 0 & ++++ & 0 & +++ & ++ \\
\hline
\end{tabular}

A
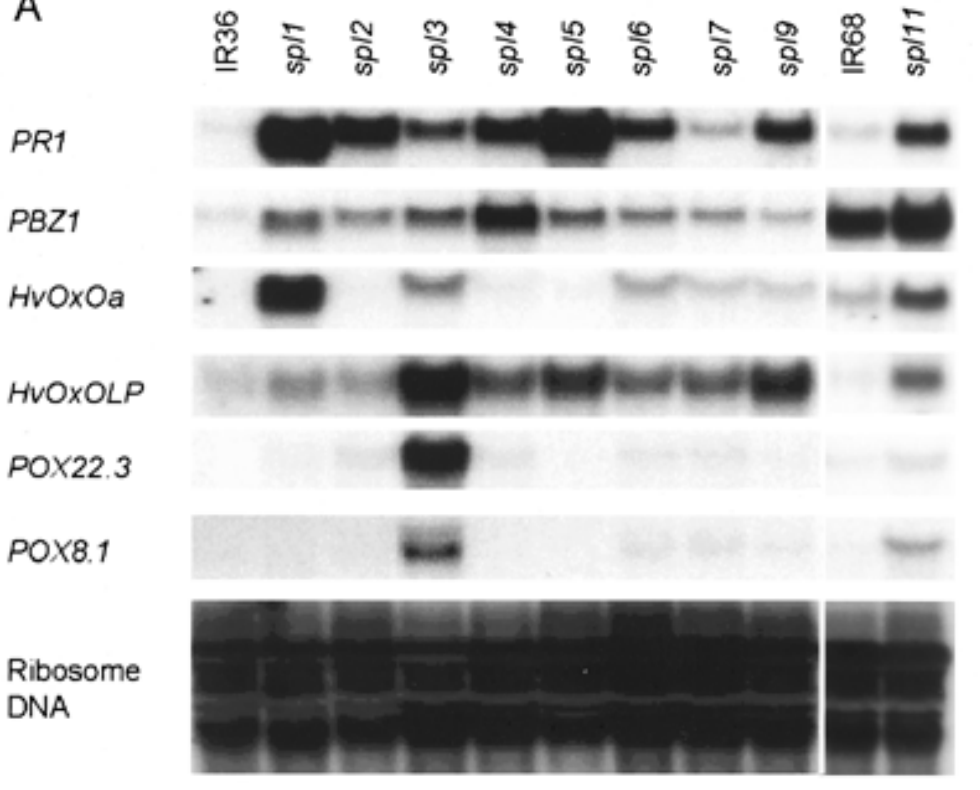

言

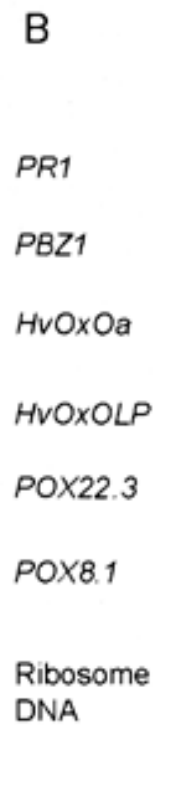

B
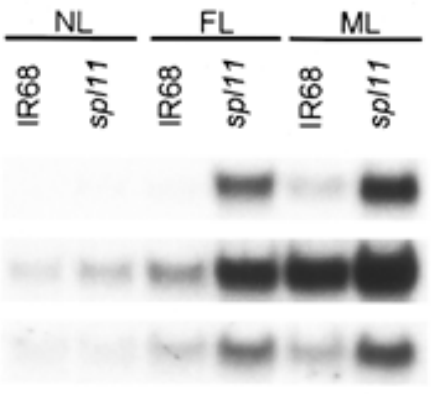

HVOXOLP

POX22.3

POX8.1

Ribosome DNA

Fig. 2. Expression of defense-related genes in $s p l$ mutants. A, Northern (RNA) blot analysis of six defense-related genes in the $s p l$ mutants and wild type. Total RNAs were extracted from mature leaves (4 weeks old) of the $s p l$ mutants with visible lesion mimic and wild-type IR36 and IR68. B, Expression of defense-related genes during lesion mimic development. Total RNAs were extracted from newly developed young leaves (less than 1 week old) without visible lesion mimic (NL), fully expanded leaves ( 2 weeks old ) with few lesion mimics (FL), and mature leaves (4 weeks old) with many lesion mimics (ML) of spl11 and leaves of wild-type IR68 at the corresponding developmental stage. 
periment, a genetic approach for eliminating the endogenous resistance genes was used (see Materials and Methods). An $\mathrm{F}_{3}$ family (S6) that segregated with lesion mimic phenotype and susceptibility to both blast and bacterial blight isolates was chosen for the inoculation experiments. Compared with plants without lesion mimic in the family, lesion mimic plants showed many fewer lesions against a Philippine blast isolate PO6-6 and short lesion length against a Philippine bacterial blight race 6 (POX99). The results were further confirmed in the $\mathrm{F}_{4}$ family with these two isolates with lesion mimic plants (spll1/spl11) and wild-type segregants (Spl11/Spl11) (Fig. 3A).

Homozygous (spl11/spl11 and Spl11/Spl11) lines from the $\mathrm{F}_{5}$ generation, nine additional blast isolates from the Philippines (9232-5, C9214-29, and CBN9219-25), China (97-55-2, 97-104-2, 97-5-1, and 54-04), Portugal (PR-3), and Colombia (CL6), and three additional bacterial blight isolates belonging to Philippine Xanthomonas oryzae pv. oryzae races 2, 3, and 4 , were used in the inoculation experiments to determine the spectrum of resistance conferred by the lesion mimic mutants. The average number of lesions in response to different isolates varied from 1 to 7 in lesion mimic plants and from 7 to 34 in wild-type plants, depending on the blast isolates inoculated (Fig. 3B). In addition, the disease lesions on the lesion mimic plants were smaller than those on wild-type plants. The disease lesions formed on lesion mimic plants were found only at the tip of the newly developed leaves where no visible lesion mimic had developed. Similarly, reduction in disease was observed with bacterial blight inoculation. The average lesion length ranged from 1.0 to $6.6 \mathrm{~cm}$ in lesion mimic plants and from 4.0 to $25.2 \mathrm{~cm}$ in wild-type plants for the different bacterial blight isolates (Fig. 3C). The broad-spectrum resistance of spll1 to bacterial blight and blast appeared to correlate with the expression of most of the defense-related genes tested in the mutant plants in which expression was only detected in fully expanded and mature leaves (Fig. 2B).

\section{DISCUSSION}

Several lesion mimic mutants have been identified in different plants, with some being dominant and some recessive (Richberg et al. 1998). These lesions may result from the improper production of signals or cell-damaging effects associated with pathogen attack (Walbot et al. 1983), alterations of disease resistance genes (Hu et al. 1996), or defects in programmed cell death pathway (Johal et al. 1995; Dangl et al. 1996). Lesion mimic phenotypes have also been produced by the over-expression of foreign genes such as cholera toxin (Beffa et al. 1995) and bacterio-opsin (Mittler et al. 1995) or

Fig. 3. Enhanced resistance to blast and bacterial blight conferred by spl11. A, Disease reaction of lesion mimic plants (spl11/spl11) (LM+) and plants with normal phenotype (Spl11/Spl11) (LM-). These plants are the progeny $\left(\mathrm{F}_{4}\right)$ of a cross of spll1 with $\mathrm{CO} 39$ in which the endogenous genes with resistance to blast and bacterial blight had been eliminated as described in Materials and Methods. Standard errors are indicated. B, Average blast lesion number (10 to 15 plants) on leaves of LM+ plants and LM- plants after they were inoculated with 10 blast isolates. C, Average lesion length of bacterial blight disease (from 15 leaves) on leaves of LM+ plants and LM- plants after they were inoculated with four bacterial blight races. Standard errors are indicated.

inhibition of protoporphyrinogen oxidase expression (Molina et al. 1999). These results are consistent with the theory that both misregulation of genes involved in programmed cell death and disruption of cellular homeostasis by a wide range of metabolic perturbations can cause cell death in plants. In

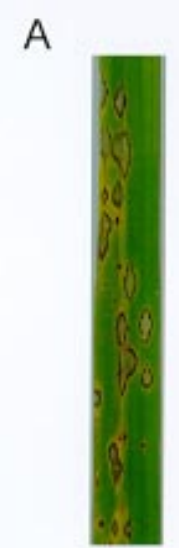

LM -

Blast isolate PO6-6

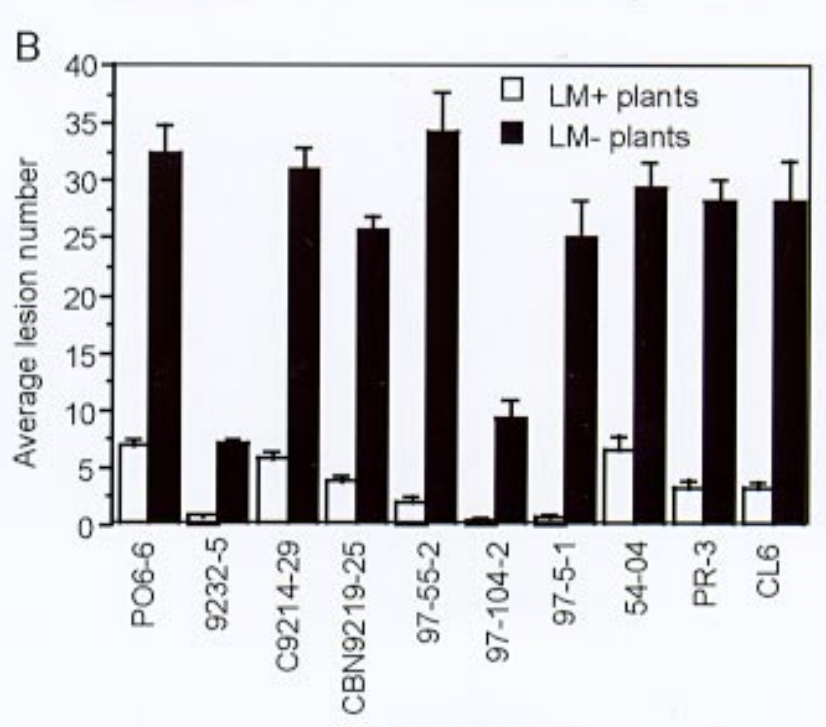

Blast isolates

C

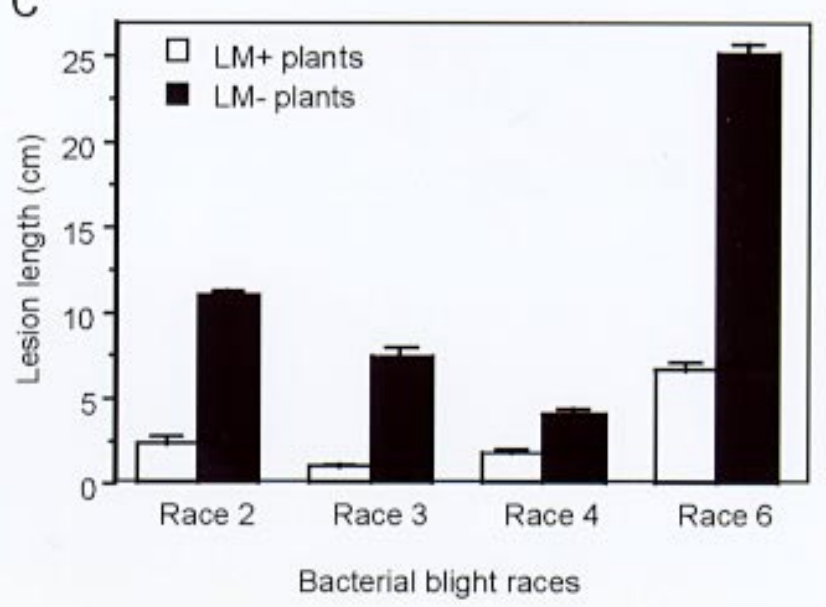


some plants, lesion formation activates the expression of cytological and biochemical markers associated with disease resistance and leads to local and systemic resistance (reviewed by Dangl et al. 1996). However, some lesion mimic genes are apparently not involved in pathogen recognition or defense response pathway, such as Les22 in maize, which encodes an enzyme in the porphyrin pathway (Hu et al. 1998).

In this study, nine rice mutants exhibiting different lesion mimic phenotypes were studied. Inoculation of nine lesion mimic mutants with blast isolates revealed four mutants (spll, spl5, spl9, and spll1) that conferred enhanced resistance to blast. The other five mutants did not display detectable enhanced resistance to the blast isolates tested although defense genes such as $P R I$ and $P B Z 1$ were activated in these mutants. Takahashi et al. (1999) described three mutants ( $c d r 1, c d r 2$, and $C d r 3$ ) with enhanced resistance to a single blast isolate. The $c d r 1$ mutant produced visible lesions about 20 days after sowing, whereas the $c d r 2$ mutant showed lesion expression about 50 days after sowing. A similar range in the expression of lesion mimics was also observed in the $s p l$ mutants, and it is possible that some of the $s p l$ mutations could be allelic to the $c d r$ mutations. However, the limited phenotypic profiles shared by the two sets of mutants preclude a direct comparison at this point.

Of the nine mutants studied, only spll1 showed resistance to multi-isolates of both blast and bacterial blight pathogens. The non-race-specific resistance shown by spll1 resembles that of the mlo gene of barley, which confers lesion mimics and non-race-specific resistance to Erysiphe graminis f. sp. hordei. Jarosch et al. (1999) reported that the mutations in the Mlo locus enhanced susceptibility to the rice blast fungus, suggesting that the resistance conferred by mlo mutations seems to be limited to powdery mildew disease. The Mlo gene may have different roles in the signal transduction pathways responsible for resistance to the rice and barley pathogens. However, spll1 is quite analogous to the Arabidopsis mutant $l s d l$, which, until now, is the only lesion mimic mutant known to confer enhanced resistance to both fungal and bacterial pathogens (Dietrich et al. 1994). It is postulated that LSD1 may negatively regulate a broad set of defense response components active against more than one species of pathogen. Similarly, the Spl11 gene may be required for either suppression of cell death caused by pathogen infection or activation of the pathogen defense response. Cloning of the spll1 gene would therefore shed light on the molecular mechanism of cell death and its relationship with broad spectrum resistance in rice. Three random amplified polymorphism DNA (RAPD) markers linked to the gene have been identified and mapped on chromosome 12 (data not shown). High-resolution mapping of the locus is in progress.

SAR is a general plant resistance resulting in an enhanced broad-spectrum resistance to diverse pathogens. Concerted expression of a battery of PR proteins and increased SA are two major biochemical hallmarks of SAR. There is accumulating evidence that the PR genes are either directly or indirectly involved in establishing enhanced resistance to pathogens and SA is the necessary signal for SAR induction. Lesion mimic mutants in Arabidopsis and maize showed increased PR gene expression and elevated SA levels when lesions were present (Dietrich et al. 1994; Greenberg et al. 1994; Morris et al. 1998), suggesting that these lesion mimic mutations may be responsible for SAR induction. However, the role of SA in the induction of SAR in rice has not been well established. Using two rice $P R$ genes, $P R I$ and $P B Z 1$, we showed that, although $P R 1$ expression was activated in all the mutants during lesion mimic development, only spll, spl5, and spll1 showed a change in expression that correlates with enhanced resistance to blast. Correlation between the expression of $P B Z 1$ and enhanced resistance to rice blast was not observed in these mutants. In contrast, Takahashi et al. (1999) reported that $P B Z 1$ expression was correlated with lesion formation in $c d r 1, c d r 2$, and $C d r 3$. Although a correlation of SA level and blast resistance was reported (Silverman et al. 1995), the SA levels in our spl lesion mimic mutants have not been measured due to a high basal level of SA in rice plants. As reported in $l s d$ mutants (Hunt et al. 1997), crossing nahG transgenic rice plants with $s p l$ mutants and evaluating the level of resistance in the progeny expressing the $n a h G$ gene and lesion mimic phenotypes could be a suitable strategy for determining the role of SA in the enhanced resistance of $s p l$ mutants.

Partial disease resistance in many crop plants is thought to contribute to the durability of disease resistance to pathogens (Wang et al. 1994). The practical question is whether the partial resistance conferred by lesion mimic mutations could be used to improve resistance against multiple diseases. Compared with the gene-for-gene resistance, the elevated resistance in most lesion mimic mutants is relatively low and is considered partial resistance. It is possible that the cell death mutations in these plants only trigger a subset of defense genes against pathogens, hence showing only a moderate resistance. A second problem with resistance mediated by lesion mimic mutations is that most of the plants have stunted growth or other abnormal characteristics that prevent the direct use of these mutations in disease resistance breeding. For instance, relative to IR68, near-isogenic spll1 mutants grow slower, flower about 1 week later, and have smaller panicles. Thus, practical use of these mutations will depend on whether the undesirable pleiotropic effects of lesion mimic mutations can be uncoupled from enhanced disease resistance by recombination or genetic engineering. From the cross between spll1 and $\mathrm{CO} 39$, we have found some recombinant progeny in the $\mathrm{F}_{6}$ generation that show fewer lesion mimics. Whether the plants with lesser expression of lesion mimics still retain enhanced resistance remains to be tested. Alternatively, spll1 plants can be re-mutagenized and screened for enhanced resistance with no undesirable agronomic characteristics. Regardless of whether lesion mimic mutations can eventually be developed into a novel resistance source for breeding programs, the mutants described in this study provide the needed genetic resource to dissect the pathways of disease resistance.

\section{MATERIALS AND METHODS}

\section{Plant materials and growth conditions.}

The nine spl mutants used in this study were bred and maintained at the International Rice Research Institute, Philippines. Rice plants were grown in a greenhouse with a temperature range of $26^{\circ} \mathrm{C}$ (night) to $32^{\circ} \mathrm{C}$ (day). To determine the occurrence of lesion mimic phenotype under aseptic conditions, the seeds of each $s p l$ mutant and the wild-type plants were surface sterilized with $20 \%$ bleach for $30 \mathrm{~min}$, rinsed three times in sterile water, and germinated on $\mathrm{MS}_{0}$ medium 
containing $0.3 \%$ phytagel in an autoclaved $1,000-\mathrm{ml}$ glass cylinder. Plants were grown until lesions appeared on the leaves in a tissue culture room at $25^{\circ} \mathrm{C}$ and $14 \mathrm{~h}$ light.

\section{Histochemical analysis.}

Since lesion mimic appears on the leaves of each mutant at different developmental stages, leaf samples (three to four leaves per sample) for trypan blue staining were harvested when visible lesion mimic could be seen. Leaves of 3-weekold plants of $s p l 1, s p l 2, s p l 3, s p l 5$, spl9, and spll1, 6-week-old plants of spl4, and 10-week-old plants of spl6 and spl7 were stained with trypan blue (Sigma, St. Louis, MO). Trypan blue staining was done as previously described (Bowling et al 1997). Briefly, plant tissues were submerged in a $70^{\circ} \mathrm{C}$ trypan blue solution $(2.5 \mathrm{mg}$ of trypan blue per $\mathrm{ml}, 25 \%$ [wt/vol] lactic acid, $23 \%$ water-saturated phenol, $25 \%$ glycerol, and $\mathrm{H}_{2} \mathrm{O}$ ), infiltrated for $10 \mathrm{~min}$, and then heated over boiling water for 2 min and left to stain overnight. After de-staining in chloral hydrate solution ( $25 \mathrm{~g}$ in $10 \mathrm{ml}$ of $\mathrm{H}_{2} \mathrm{O}$ ) for 3 days, samples were equilibrated with $70 \%$ glycerol for microscopy analysis.

\section{Rice blast and bacterial blight inoculation.}

Isolates of Magnaporthe grisea, PO6-6, 9232-5, C9214-29, CBN9219-25, 97-55-2, 97-104-2, 97-5-1, and 54-04 (from IRRI, Philippines) and PR-3 and CL6 from Portugal and Colombia, respectively (gift of Didier Tharreau) were used in the inoculation experiments. Three-week-old rice plants were inoculated with blast suspension spores with a concentration of $1 \times 10^{5}$ spores per $\mathrm{ml}$. The inoculated plants were placed in a dew chamber for $24 \mathrm{~h}$ at $26^{\circ} \mathrm{C}$ and subsequently transferred to a growth chamber under $12 \mathrm{~h}$ light, $12 \mathrm{~h}$ dark, $25^{\circ} \mathrm{C}$, and $90 \%$ relative humidity. Disease reaction of the inoculated plants was scored 6 to 7 days after inoculation with the scoring system described by Bonman et al. (1986).

For bacterial blight inoculation, rice bacterial blight strains were grown on PSA medium ( $10 \mathrm{~g}$ of peptone per liter, $10 \mathrm{~g}$ of sucrose per liter, $1 \mathrm{~g}$ of glutamic acid per liter, $16 \mathrm{~g}$ of Bacto agar per liter and $\mathrm{pH}$ 7.0). Rice plants (7 to 8 weeks old) were inoculated with four Xanthomonas oryzae pv. oryzae isolates of the Philippines, race 2 (PXO086), race 3 (PXO79), race 4 (POX113), and race 6 (PXO99), with a bacterial suspension with a density of 0.5 at $\mathrm{OD}_{600}$. At least three fully expanded leaves from a single plant were inoculated by the leaf clipping method (Kauffman et al. 1973). Inoculated plants were maintained in a greenhouse and lesion lengths were measured 2 weeks after inoculation.

\section{Elimination of endogenous genes with resistance to blast and bacterial blight in spl11.}

spl11 is an EMS mutant of IR68 that carries several unknown genes with resistance to rice blast and bacterial blight. The resistance genes in IR68 were eliminated by crossing it with $\mathrm{CO} 39$ (male parent). $\mathrm{F}_{1}$ plants were self-pollinated to produce $F_{2}$ populations. The $F_{2}$ plants were inoculated with both the blast isolate PO6-6 and the bacterial blight isolate PXO99. Plants susceptible to both the pathogen isolates without lesion mimic phenotype were selected to produced the $\mathrm{F}_{3}$ families. $\mathrm{F}_{3}$ families that segregated for lesion mimic phenotype were self-pollinated and the derived homozygous $F_{4}$ and $\mathrm{F}_{5}$ plants of wild-type and lesion mimic phenotypes were used for disease resistance evaluation for blast and bacterial blight.

\section{Northern (RNA) analysis.}

Leaf samples for RNA isolation were collected from 2month-old plants. Total RNA was isolated with TRIZOL Reagent (Life Technologies, Gaithersburg, MD). Approximately $10 \mu \mathrm{g}$ of RNA per lane was separated with $1 \%$ formaldehydeagarose gels and transferred to a Hybond- $\mathrm{N}^{+}$membrane (Amersham, Buckinghamshire, UK) according to instructions provided by the manufacturer. ${ }^{32} \mathrm{P}$-labeled DNA probes were labeled with the Rediprime DNA labeling system (Amersham, Buckinghamshire, UK). Rapid hybridization solution (Clonetech, Palo Alto, CA) was used in Northern hybridization.

Six defense-related genes were used in the Northern analysis of $s p l$ mutants. The probes for PRI (accession number U89895) and PBZ1 (accession number D38170) genes were $A p a \mathrm{I}-\mathrm{SacI}$ fragments released from plasmids containing the cDNA clones (Takahashi et al. 1999). The probes used for POX22.3 and POX8.1 genes were the 3' untranslated regions of the genes generated by polymerase chain reaction from plasmids containing the cDNA clones, with primers described by Chittoor et al. (1997). The probes for $\mathrm{HvOxOa}$ (Zhou et al. 1998) and HvOxOLP (Wei et al. 1998) genes were generated by polymerase chain reaction from plasmids containing the cDNA clones. RNA blots were also probed with the ribosome DNA probe as an internal control.

\section{ACKNOWLEDGMENTS}

L. Z. is supported by a grant from the Rockefeller Foundation to G.L. W. and H. L. We also thank Didier Tharreau for providing blast isolates, Jan Leach for providing the peroxidase genes, Ko Shimamoto for providing two $P R$ protein genes ( $P R 1$ and $P B Z 1$ ), and David B. Collinge for providing barley oxalate oxidase and oxalate oxidase-like genes.

\section{LITERATURE CITED}

Baker, C. J., and Orlandi, E. W. 1995. Active oxygen in plant pathogenesis. Annu. Rev. Phytopathol. 33:299-322.

Beffa, R., Szell, M., Meuwly, P., Pay, A., Vogeli-Lange, R., Metraux, J.P., Neuhaus, G., Meins, F., Jr., and Nagy, F. 1995. Cholera toxin elevates pathogen resistance and induces pathogenesis-related gene expression in tobacco. EMBO J. 14:5753-5761.

Bent, A. F. 1996. Plant disease resistance genes: Function meets structure. Plant Cell 8:1757-1771.

Bonman, J. M., Vergel de Dios, T. I., and Khin, M. M. 1986. Physiologic specialization of Pyricularia oryzae in the Philippines. Plant Dis. 70: 767-769.

Bowling, S. A., Clarke, J. D., Liu, Y., Klessig, D. F., and Dong, X. 1997. The cpr5 mutant of Arabidopsis expresses both NPR1-dependent and NPR1-independent resistance. Plant Cell 9:1573-1584.

Buschges, R., Hollricher, K., Panstruga, R., Simons, G., Wolter, M., Frijters, A., van Daelen, R., van der Lee, T., Diergaarde, P., Groenendijk J., Topsch, S., Vos, P., Salmini, F., and Schulze-Lefert, P. 1997. A novel control element of plant pathogen resistance. Cell 88:695-705.

Chittoor, J. M., Leach, J. E., and White, F. F. 1997. Differential induction of a peroxidase gene family during infection of rice by Xanthomonas oryzae pv. oryzae. Mol. Plant-Microbe Interact. 10:861-871.

Dangl, J. L., Dietrich, R. A., and Richberg, M. H. 1996. Death don't have no mercy: Cell death programs in plant-microbe interactions. Plant Cell 8:1793-1807.

Dietrich, R. A., Delaney, T. P., Uknes, S. J., Ward, E. R., Ryals, J. A., and Dangl, J. L. 1994. Arabidopsis mutants simulating disease resistance response. Cell 77:565-577.

Dietrich, R. A., Richberg, M. H., Schmidt, R., Dean, C., and Dangl, J. L. 1997. A novel zinc-finger protein is encoded by the Arabidopsis LSDI gene and functions as a negative regulator of plant cell death. Cell 88: 685-694.

Gaffney, T., Friedrich, L., Vernooij, B., Negrotto, D., Nye, G., Uknes, S., Ward, E., Kessmann, H., and Ryals, J. 1993. Requirement of salicylic 
acid for the induction of systemic acquired resistance. Science 261: 754-756.

Gaspar, T., Penel, C., Thorpe, T., and Greppin, H. 1982. Peroxidases: A Survey of Their Biochemical and Physiological Roles in Higher Plants. University of Geneva Press, Geneva.

Gray, J., Close, P. S., Briggs, S. P., and Johal, G. S. 1997. A novel suppressor of cell death in plants encoded by the Lls1 gene of maize. Cell 89:25-31.

Greenberg, J. T., and Ausubel, F. M. 1993. Arabidopsis mutants compromised for the control of cellular damage during pathogenesis and aging. Plant J. 4:327-341.

Greenberg, J. T., Guo, A., Lessig, D. F., and Ausubel, F. M. 1994. Programmed cell death in plants: A pathogen-triggered response activated coordinately with multiple defense functions. Cell 77:551-564.

Hammond-Kosack, K. E., and Jones, J. D. G. 1996. Resistance genedependent plant defense responses. Plant Cell 8:1773-1791.

Hu, G., Richter, T. E., Hulbert, S. H., and Pryor, T. 1996. Disease lesion mimicry caused by mutations in the rust resistance gene $r p 1$. Plant Cell 8:1367-1376.

Hu, G., Yalpani, N., Briggs, S. P., and Johal, G. S. 1998. A porphyrin pathway impairment is responsible for the phenotype of a dominant disease lesion mimic mutant of maize. Plant Cell 10:1095-1105.

Hunt, M. D., Delaney, T. P., Dietrich, R. A., Weymann, K. B., Dangl, J. L., and Ryals, J. A. 1997. Salicylate-independent lesion formation in Arabidopsis lsd mutants. Mol. Plant-Microbe Interact 10:531-536.

Jarosch, B., Kogel, K.-H., and Schaffrath, U. 1999. The ambivalence of the barley Mlo locus: Mutations conferring resistance against powdery mildew (Blumeria graminis f. sp. hordei) enhance susceptibility to the rice blast fungus Magnaporthe grisea. Mol. Plant-Microbe Interact. 12:508-514

Johal, G. S., Hulbert, S., and Griggs, S. P. 1995. Disease lesion mimic mutations in maize: A model for cell death in plants. BioEssays 17: 685-692.

Jorgensen, J. H. 1992. Discovery, characterization and exploitation of Mlo powdery mildew resistance in barley. Euphytica 63:141-152.

Kauffman, H. E., Reddy, A. P. K., Hsieh, S. P. Y., and Merca, S. D. 1973 An improved technique for evaluating resistance of rice varieties to Xanthomonas oryzae. Plant Dis. Rep. 57:537-541.

Kinoshita, C. T. 1995. Report of committee on gene symbolization, nomenclature and linkage groups. Rice Genet. Newsl. 12:9-115.

Kiyosawa, S. 1970. Inheritance of a particular sensitivity of the rice variety, Sekiguchi Asahi, to pathogens and chemicals, and linkage relationship with blast resistance. Bull. Nat. Inst. Agric. Sci. (Jpn.) Ser. D. Physiol. Genet. 21:61-71.

Kliebenstein, D. J., Dietrich, R. A., Martin, A. C., Last, R. L., and Dangl, J. L. 1999. LSD1 regulates salicylic acid induction of copper zinc superoxide dismutase in Arabidopsis thaliana. Mol. PlantMicrobe Interact. 12:1022-1026.

Low, P. S., and Merida, J. R. 1995. The oxidative burst in plant defense: Function and signal transduction. Physiol. Plant. 96:533-542.

Marchetti, M. A., Bollich, C. N., and Uecker, F. A. 1983. Spontaneous occurrence of the Sekiguchi lesion in two American rice lines: Its induction, inheritance, and utilization. Phytopathology 73:603-606.

Midoh, N., and Iwata, M. 1996. Cloning and characterization of a probenazole-inducible gene for an intracellular pathogenesis-related protein in rice. Plant Cell Physiol. 37:9-18.

Mittler, R., Shulaev, V., and Lam, E. 1995. Coordinated activation of programmed cell death and defense mechanisms in transgenic tobacco plants expressing a bacterial proton pump. Plant Cell 7:29-42.

Molina, A., Volrath, S., Guyer, D., Maleck, K., Ryals, J., and Ward, E. 1999. Inhibition of protoporphyrinogen oxidase expression in Arabidopsis causes a lesion-mimic phenotype that induces systemic acquired resistance. Plant J. 17:667-678.

Morris, S. W., Vernooij, B., Titatarn, S., Starret, M., Thomas, S., Wiltse, C. C., Frederiksen, R. A., Bhandhufalck, A., Hulbert, S., and Uknes, S. 1998. Induced resistance responses in maize. Mol. Plant-Microbe Interact. 11:643-658.

Richberg, M. H., Aviv, D. H., and Dangl, J. L. 1998. Dead cells do tell tales. Curr. Opin. Plant Biol. 1:480-485.

Ryals, J. A., Neuenschwander, U. H., Willits, M. G., Molina, A., Steiner, H. Y., and Hunt, M. D. 1996. Systemic acquired resistance. Plant Cell 8:1809-1819.

Schweizer, P., Buchala, A., Dudler, R., and Metraux, J. P. 1998. Induced systemic resistance in wounded rice plants. Plant J. 14:475-481.

Silverman, P., Seskar, M., Kanter, D., Schweizer, P., Metraux, J. P., and Raskin, I. 1995. Salicylic acid in rice. Plant Physiol. 108:633-639.

Simmons, C., Hantke, S., Grant, S., Johal, G. S., and Briggs, S. P. 1998. The maize lethal leaf spot 1 mutant has elevated resistance to fungal infection at the leaf epidermis. Mol. Plant-Microbe Interact. 11:1110-1118.

Singh, K., Multani, D. S., and Khush, G. S. 1995. A new spotted leaf mutant in rice. Rice Genet. Newsl. 12:192-193.

Takahashi, A., Kawasaki, T., Henmi, K., Shii, K., Kodama, O., Satoh, H., and Shimamoto, K. 1999. Lesion mimic mutants of rice with alterations in early signaling events of defense. Plant J. 17:535-545.

Walbot, V., Hoisington, D. A., and Neuffer, M. G. 1983. Disease lesion mimics in maize. Pages 431-442 in: Genetic Engineering of Plants. T. Kosuge and C. Meredith, eds. Plenum Publishing, New York.

Wang, G. L., Mackill, D. J., Bonman, J. M., McCouch, S. R., Champoux, M. C., and Nelson, R. J. 1994. RFLP mapping of genes conferring complete and partial resistance to blast in a durably resistant rice cultivar. Genetics 136:1421-1434.

Ward, E. R., Uknes, S. J., Williams, S. C., Dincher, S. S., Wiederhold, D. L., Alexander, D. C., Ahl-Goy, P., Metraux, J.-P., and Ryals, J. A. 1991. Coordinate gene activity in response to agents that induce systemic acquired resistance. Plant Cell 3:1085-1094.

Wei, Y., Zhang, Z., Andersen, C. H., Schmelzer, E., Gregersen, P. L., Collinge, D. B., Smedegaard-Petersen, V., and Thordal-Christensen, H. 1998. An epidermis/papilla-specific oxalate oxidase-like protein in the defence response of barley attacked by the powdery mildew fungus. Plant Mol. Biol. 36:101-112.

Wolter, M., Hollricher, K., Salamini, F., and Schulze-Lefert, P. 1993. The mlo resistance alleles to powdery mildew infection in barley trigger a developmentally controlled defence mimic phenotype. Mol. Gen. Genet. 239:122-128.

Yang, Y., Shah, J., and Klessig, D. F. 1997. Signal perception and transduction in plant defense responses. Genes Dev. 11:1621-1639.

Zhou, F., Zhang, Z., Gregersen, P. L., Mikkelsen J. D., Neergaard, E., Collinge, D. B., and Thordal-Christensen, H. 1998. Molecular characterization of the oxalate oxidase involved in the response of barley to the powdery mildew fungus. Plant Physiol. 117:33-41. 